\title{
SEISMITE AND TSUNAMIITE IN URBAN ENVIRONMENT (LISBON)
}

\author{
ANA RAMOS-PEREIRA ${ }^{1}$ \\ JORGE TRINDADE ${ }^{2}$ \\ JOÃO ARAÚJO-GOMES ${ }^{3}$
}

Since the Malta convention in 1992, the Portuguese law determines that all works affecting the basement/subsoil must be monitored by an archeological team, That was the case concerning the new Museum of Carriages (Museu dos Coches) in the present day noble urban area of Belém, where the demolition of existing buildings began in the spring of 2008 (fig. $1 \mathrm{a}$ and b).

In July 2008, the SLIF team was contacted by the archeological team in charge in order to survey several outcrops. This survey was made possible by the opening of some ditches/ trenches (fig. 1c). Field work and data collection of a few outcrops was only permitted in a flash site intervention $(2 \mathrm{~h} 30 \mathrm{~m})$ and was hampered by the urgency of the construction works and by the rising tide.

The first results were presented in Vienna, during the General Assembly 2010 of the European Geosciences Union (Ana Ramos-Pereira et al., 2010).

The authors decided to present here a brief note given the importance of the data collected, e.g., seismic manifestation in a sedimentary context (seismite) as well as the sedimentary tsunamic layer (tsunamiite), but also because the data is very important not only from the scientific point of view but also for spatial planning of an urban area.

\section{THE METHODOLOGICAL APPROACH}

The available time allowed the team to:

(i) perform a field survey of the surrounding area in order to establish the outcrops geomorphological framework;

1 Associated Professor of IGOT-UL; Researcher at CEG-IGOT-UL, Research Group SLIF Coastal and Fluvial Systems: Dynamics, Environmental Changes and Management. E-mail: anarp@, campus.ul.pt

2 Professor of the Open University (Universidade Aberta); Researcher at the CEG-IGOT-UL, Research Group SLIF; E-mail: jorgetrd@uab.pt

3 PhD Student (FCT), Researcher at CEG-IGOT-UL, Research Group SLIF. E-mail: joaopgomes@campus.ul.pt 

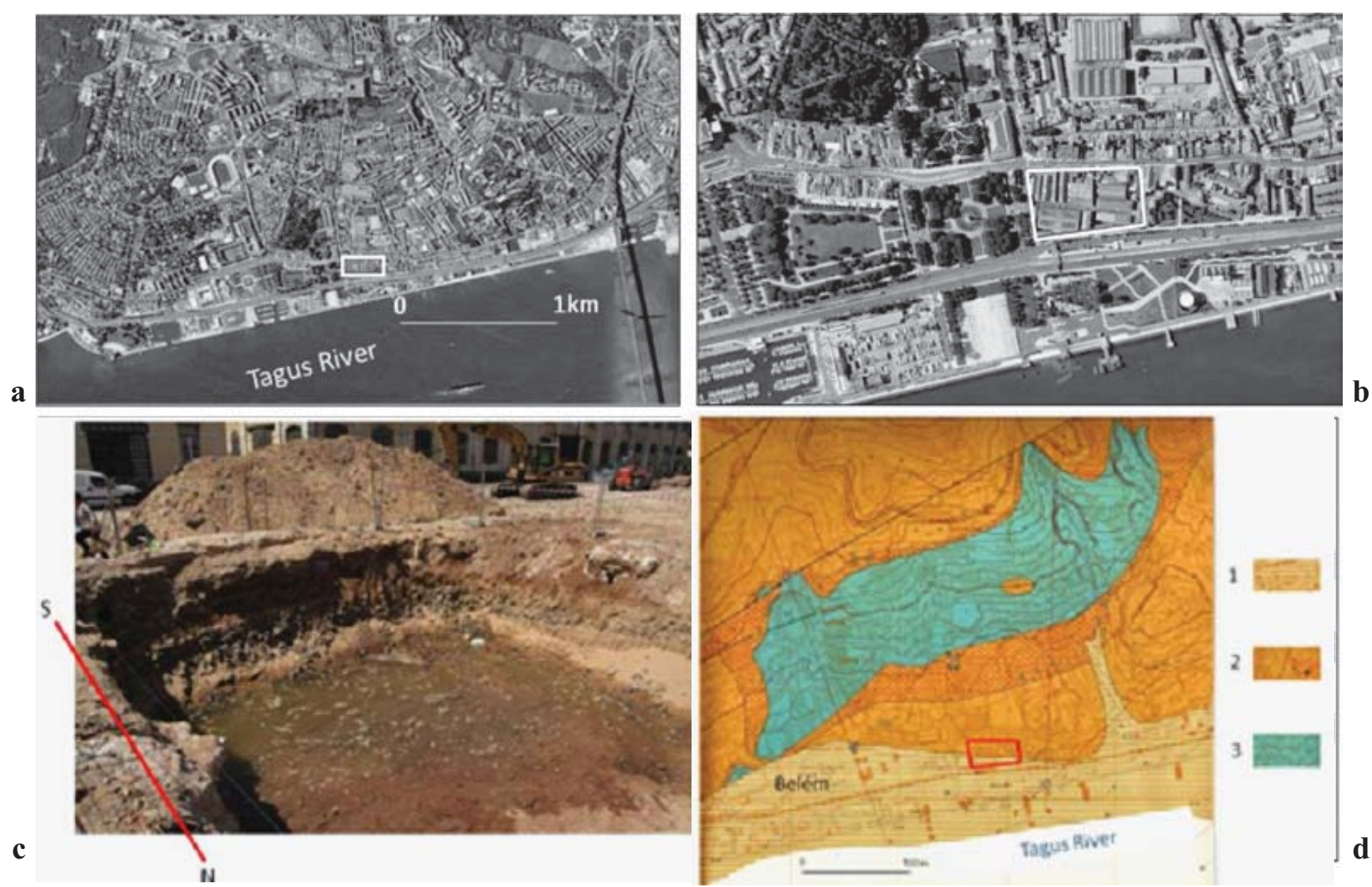

b

Fig. 1 - The studied area of Belém (Lisbon), near the Tagus River, (a) and (b) before the beginning of the urban renewal and view of one of the ditches in July 2008 (c). Geological map (d), where 1 - "LVC" cover by landfill (Upper Holocene), 2 - "Lisbon Volcanic Complex" (LVC) (Neocretaceous), 3 - Limestones (Upper Cenomanian), Moitinho de Almeida (1986).

(See coloured version online)

Fig. 1 - A área estudada de Belém (Lisboa), perto do Rio Tejo, (a) e (b) antes do início da renovação urbana, e aspeto de uma das sanjas em Julho de 2008 (c). Mapa geológico, onde 1 - "CVL" coberto por aterro (Holocénico final), 2 - "Complexo Vulcânico de Lisboa" (CVL) (Neocretácico), 3 - Calcários (Cenomaniano Superior), Moitinho de Almeida (1986).

(ii) perform a field survey of $5(6 \mathrm{mx} 5 \mathrm{~m})$ rectangular outcrops, with $3 \mathrm{~m}$ maximum depth, in order to select those for detail analysis;

(iii) compile a photographic record;

(iv) georeference the morphologic and sedimentologic elements of the site;

(v) make a field analysis of the exposed deposits - a beach deposits - and identify several beach layers (sandy and pebble);

(vi) collect sediment samples;

(vii) make systematic measurements of the slope angle axis of the imbricate rounded clasts for paleocurrents research.

In order to complement this approach some samples were treated in the Physical Geography Lab of the Centre for Geographical Studies, using classic sedimentological laboratory procedures to determinate sediment descriptive statistics. Some research has been done on historical data and mapping.

Only one of the outcrops is presented here, its geomorphological framework and the previous results of the analyzed samples. 


\section{THE STUDIED SITE}

The area submitted to urban renewal is situated on the right bank of the estuary of the Tagus River (fig. 1a and b). The northern slope of the estuary is cut in limestones and rocks of CVL (fig.1d). Its southern bottom is the current street of Junqueira (Rua da Junqueira), with a shore platform cut in LVC, still visible in one of the ditches.

The deposits show the LVC basement overlaped by several deposits, hidden by the landfill.

When interpreting deposits hidden by landfill it is important to understand the riverside landscape prior to the current situation. Glazed tile panels of Belém's surroundings in the early XVIII century (CML, 2004) show the north riverside as a slope crossed by several small streams (the Ribeira da Ajuda and Alcântara examples), with small palaces and numerous farms. A bare strip of land, presumably beach and marsh connected Belém with the river. According to Barata (2009), in the eighteenth century the north river bank of the Tagus River was a set of muddy beaches where city waste and filth was dumped. Recognized as a local dump for all sorts of refuse and therefore a latent threat to public health of city residents, several solutions were proposed by Engineers and Architects since the XVII century.

The first area to be submitted to urban intervention by the Town Hall was the area of the landfill called Aterro da Boa Vista (also called O Grande Aterro), which constitutes one of the country's major public works in the nineteenth century, connecting Cais do Sodré to Alcântara and allowing the opening of the current Av. 24 de Julho.

The same environmental situation occurred in Bom Sucesso near Belém, which was an industrial neighborhood.

The present scenery along the river is therefore the result of years of small changes and major works. Landfill hid this landscape, but it can be deduced from data found in various ditches opened in 2008 .

\section{THE DEPOSITS}

Figure 2 illustrates the outcrop where several layers have been identified:

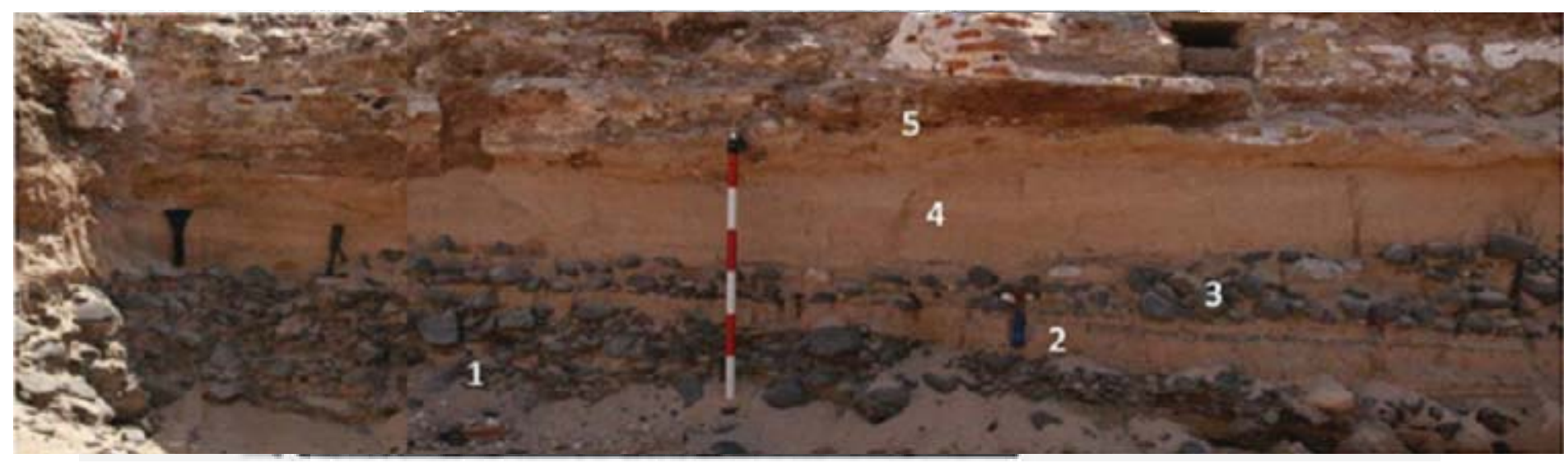

Fig. 2 - Studied outcrop in Belém. The layers 1 to 5 are explained in the text.

(See coloured version online)

Fig. 2 - Corte geológico estudado em Belém. Os leitos 1 a 5 estão explicados no texto. 
1 - a massive layer with round basaltic gravel, pebbles and cobbles, over $20 \mathrm{~cm}$ maximum diameter, dipping $8^{\circ} \mathrm{SSW}$;

2 - a medium sand layer, ending in a wedge shape to the North, with planar cross bedding, dipping $2^{\circ}$ South, and inter-bedded heavy mineral lamminae;

3 - a chaotic layer with gravel, pebbles and cobbles (basaltic and some rare limestone; see fig. 1d) in a sandy matrix, thinner to the North (inland), where it disappears;

4 - a medium sand layer similar to layer 2;

5 - artificial landfill.

Several samples from layers 2, 3 and 4 (fig. 2) have been collected and sand analyzed for statistical characterization with Gradistat (Blott \& Pye, 2001). All the sands are medium sand, unimodal, well sorted, with symmetrical and mesokurtic distribution, with the exception of sand of layer 3 (samples B3-4 and B3-5; fig. 3), which are coarse sand, bimodal, poorly sorted, very coarse to very fine skewed and very platikurtic.

Other details must be noted: the disturbance features in layers 2 and 3. As mentioned above the sands of this two layers have heavy minerals laminae, particularly well defined in level 2. However, these laminae show several disturbance features, which are not present in sand layer 4.

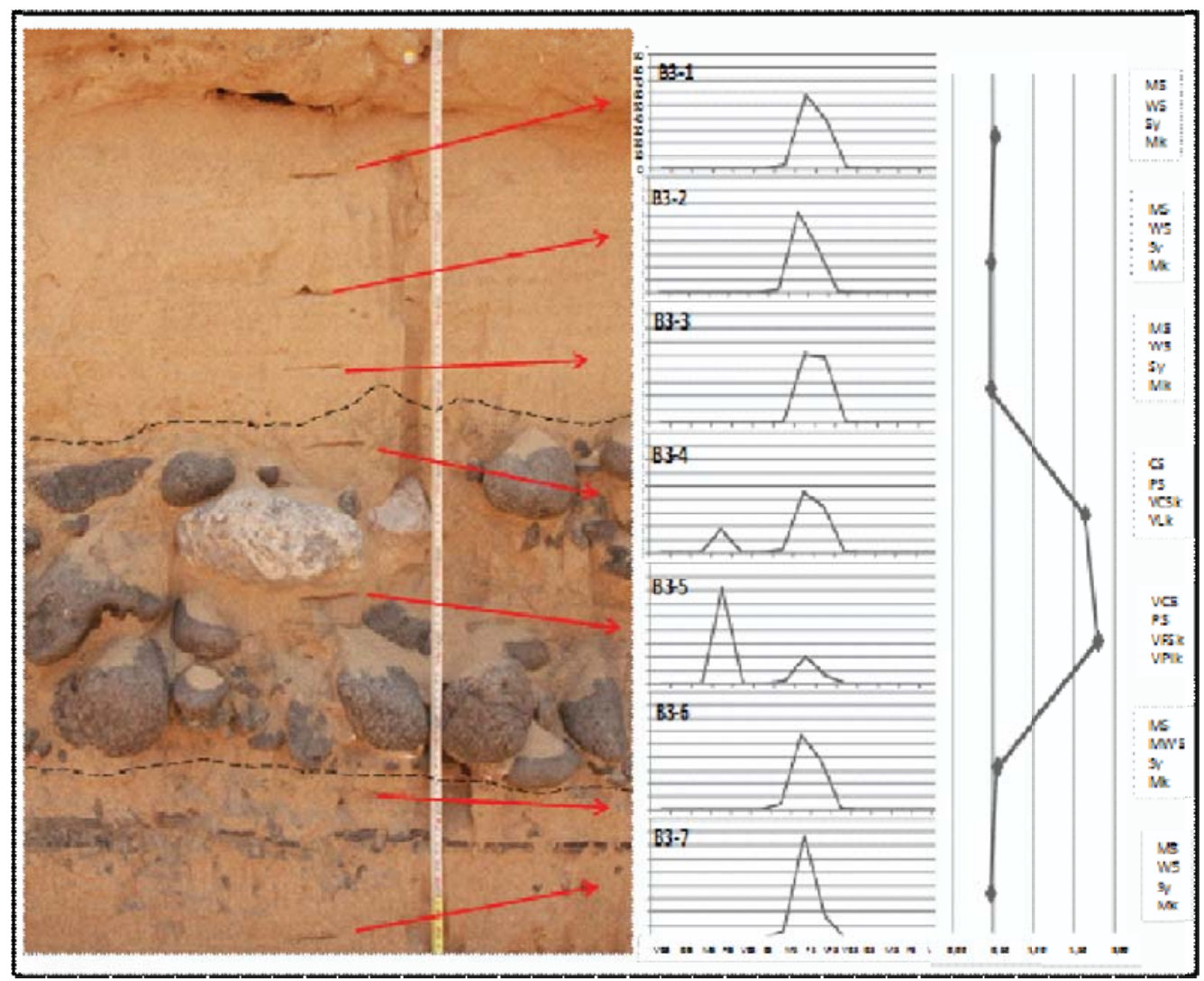

Fig. 3 - A detail of the studied outcrop and the results of sand statistical parameters. The arrows show the position of the samples and their sand results. The dashed line limits the layer 3 of Fig. 2.

(See coloured version online)

Fig. 3 - Pormenor do corte estudado e resultado dos parâmetros estatísticos das areias. As setas indicam a posição das amostras e os respetivos resultados. As linhas tracejadas delimitam o nível 3 da Fig. 2. 
These features can be wavy like, discontinuities, sand injections, flames, heavy metal diffusion, and drops and dendritic and/or root like (fig. 4).
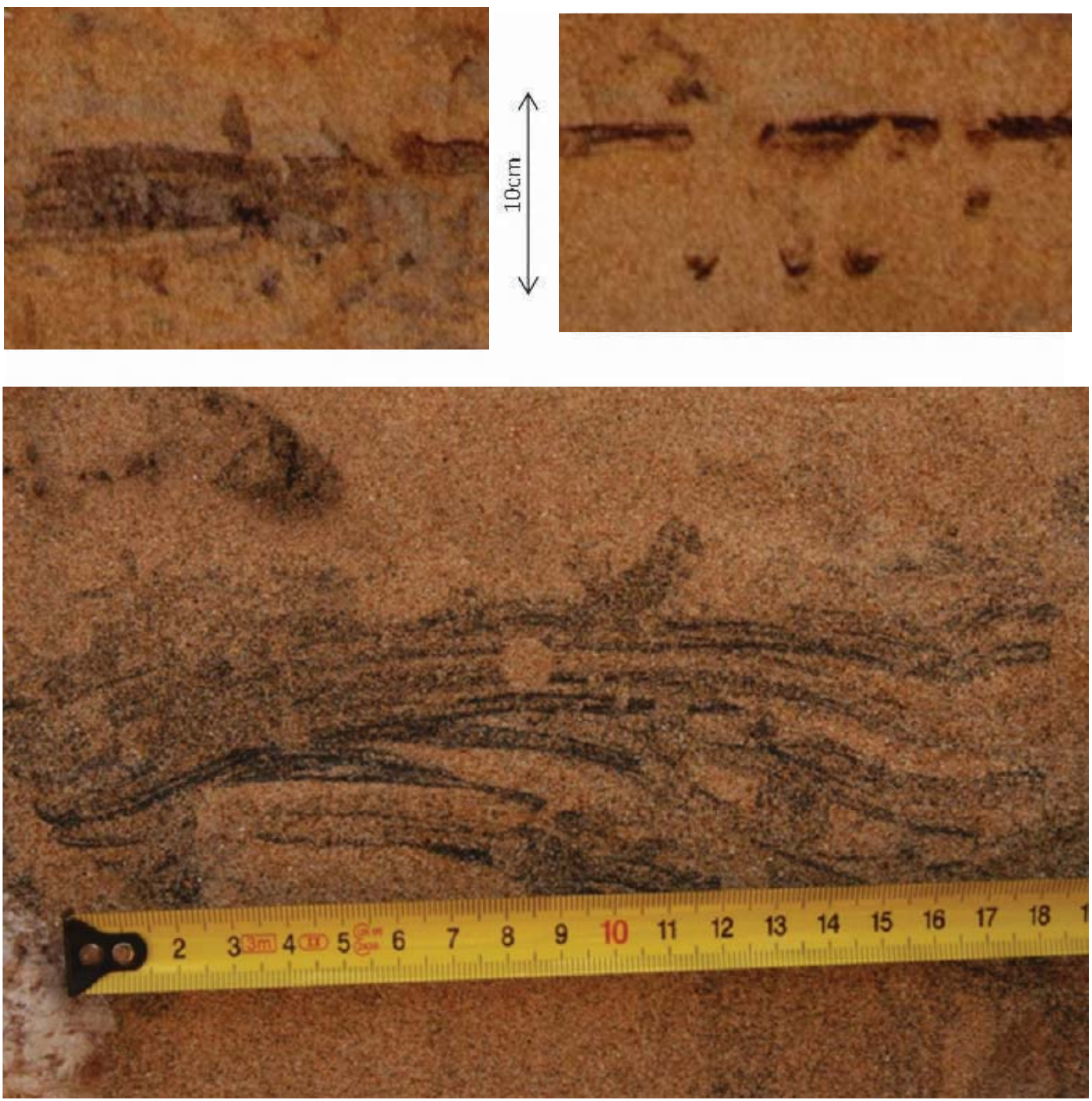

Fig. 4 - Some examples of the disturbance features of the heavy minerals laminae in layers 2 and 3. (See coloured version online)

Fig. 4 - Alguns exemplos de assinaturas de deformação a afetar as laminas de minerais pesados nos níveis 2 e 3 .

\section{FINAL REMARKS}

The results show an estuarine beach deposits with basaltic boulder and gravel layer at the bottom (layer 1), followed by a sand beach with abundant heavy mineral laminae (layer 2), both dipping to the South. 
The disturbance inside layer 2 seemed to be related to liquefaction (considered by Olson et al. (2005) and Obermeier et al. (2005), as a transformation of a saturated granular material from a solid to a liquefied state, which might be induced by seismic shaking) and fluidization. Nikolaeva (2009) summarizes the following main criteria for liquefaction and fluidization: (i) "composition of sediments prone to plasticity, liquefaction, and fluidization; (ii) absence of detectable effects of slope instability; (iii) independence of deformation structures of sediment stacking patterns; (iv) stratigraphic position of deformation units between undeformed sediments; (v) cyclic repetition of structures in the section as evidence for recurrence of the causative events; (vi) similarity to structures proven to result from seismic shaking; (vii) proximity to an active seismic zone and (viii) proximity to faults which have been active through the Cenozoic".

The case study fulfills all requirements as the sediment is sand lying in a gentle slope, exhibiting disturbance features as described by Araújo-Gomes (2013) and the site is in a seismic zone, with historical seism. The large well documented seism (the so called Lisbon earthquake 1755) had an estimated magnitude of 8.5-9.0 (Gutscher et al., 2006). According to several authors, Obermeier et al. (2005) refers that the minimum earthquake magnitude to form liquefaction features is about moment magnitude M 5.5, a value widely exceeded by the 1755 earthquake.

The authors considered layer 2 as a seismite.

The layer 3 differs from layer 1 due to the presence of limestone pebbles and its chaotic distribution in a sand matrix (absent in layer 1), beyond finishing and dipping inland. The sand has a bimodal distribution, which is a common characteristic of tsunami-induced depositions (Scheffers \& Kelletat, 2004). The presence of disturbance features inside layer 3 (tsunamiite) agree with the occurrence of replicas with magnitude exceeding M 5.

Sand layer 4 is not disturbed, even the heavy mineral laminae.

Moreover, two human skeletons were found on the analogous stratigraphic layer of layer $3 .{ }^{14} \mathrm{C}$ dating of the remains showed their age to be consistent with middle $18^{\text {th }}$ century. Therefore, it is acceptable to propose that a strong relation between a destructive episode and the death of those two individuals was not a coincidence.

It is the first time that the 1755 seismite and tsunamiite are identified in the Lisbon urban area.

\section{FUTURE RESEARCH}

The object of the current research is the urban area of Belém (western Lisbon), with approximately $17,000 \mathrm{~m}^{2}$, that evolved from essentially rural to markedly urban areas.

The data mentioned above is part of a dataset collected from 2008 to 2010 that allow assessing the pre-tsunami landscape features and their evolution in order to define the geomorphological constrains of the tsunami flooded area along the river bank. The time window addressed include human intervention described in historical documents.

A multidisciplinary approach will be developed using geomorphology, sedimentary and geochemical data, historical documents and urban plans, radiocarbon dating and modeling paleolandscape in $2 \mathrm{D}$ and $3 \mathrm{D}$.

\section{ACKNOWLEDGMENTS}

The archaeological information and the ${ }^{14} \mathrm{C}$ dating was kindly given to us by the archaeological enterprise Arqueohoje, Conservação e Restauro do Património Monumental LDA. 


\section{REFERENCES}

Araújo-Gomes (2013) Deformações em sedimentos finos não consolidados interpretadas como sismitos. Finisterra - Revista Portuguesa de Geografia.

Barata A Martins (2009) A ordenação do espaço litoral de Lisboa, 1860-1940. Scripta Nova. Revista Electrónica de Geografía y Ciencias sociales. Barcelona: Universidad de Barcelona, de de 2009, vol. XIII, núm. 296 (4) http:// www.ub.es/geocrit/sn/sn-266-4.htm. [ISSN: 1138-9788] [Acceded September 2012].

Blott S J, Pye K (2001) GRADISTAT: a grain size distribution and statistics package for the analysis of unconsolidated sediments. Earth Surface Processes and Landforms, 26: 1237$-1248$.

CML (2004) Lisboa antes do terramoto. Grande vista da cidade entre 1700 e 1725. Câmara Municipal de Lisboa, Gótica- Chardeigne.

Gutscher M-A, Baptista M A, Miranda J M (2006) The Gibraltar Arc seismogenic zone (part 2): constraints on a shallow east dipping fault plane source for the 1755 Lisbon earthquake provided by tsunami modeling and seismic intensity. Tectonophysics, 426:153-166.

Nikolaeva S B (2009) Seismites in Late Pleistocene and Holocene deposits of the northwestern Kola region (northern Baltic Shield). Russian Geology and Geophysics, 50: 644-650.

Olson, S M, Green R A, Obermeier S F (2005) Geotechnical analysis of paleoseismic shaking using liquefaction effects: a major updating. Engineering Geology, 76: 235-261.

Obermeier S F, Olson S M, Green R A (2005) Field occurrences of liquefaction-induced features: a primer for engineering geologic analysis of paleoseismic shaking. Engineering Geology, 76: 209-234.

Ramos-Pereira A, Trindade J, Araújo-Gomes J, Gusmão F (2012) Evidences of the 1755 Lisbon earthquake in urban environment (Lisbon). Geophysical Research Abstracts Vol. 12, EGU2010-9665, $2010 \mathrm{http}: / /$ meetingorganizer.copernicus.org/EGU2010/EGU2010-9665. pdf [Acceded September 2012].

Scheffers A, Kelletat D (2004) Bimodal tsunami deposits - a neglected feature in paleo-tsunami research. G. Schernewski und T. Dolch (Hrsg.): Geographie der Meere und Küsten, Coastline Reports 1), ISSN 0928-2734, S. 67-75. 